\title{
Mediating Role of Halal Technology Implementation on Halal Purchase Intention in Semarang
}

\author{
Fania Mutiara Savitri \\ Fakultas Dakwah dan Komunikasi, Universitas Islam Negeri Walisongo Semarang \\ Email: faniamutiara@walisongo.ac.id \\ Atika Dyah Perwita \\ Fakultas Ilmu Tarbiyah dan Keguruan, Universitas Islam Negeri Walisongo Semarang \\ Email: atikadyah@walisongo.ac.id
}

\begin{abstract}
This study aimed to analyze halal purchase intention that is mediated by halal technology implementation on packaging product in Semarang City, Indonesia. This analysis tried to build the concept of consumer behavior based on Islamic branding technology. The research model was developed through research variables to fill existing research gap between halal awareness and halal purchase intention by halal technology implementation. This technology able to detect halal label validated by MUI that is expected to mediate both variable. Research approach used quantitative approach. Data was collected by survey questionnaire methods for packaging product's consumer in Semarang. This research used purposive sampling to obtain 100 consumers as data observation. SEM analysis was used to analyze the data through running Smart PLS 3.2.8 for Professional application for hypothesis testing. The finding presented that Consumer Behavior based on Islamic Branding Technology Concept is proven. It is proved by significant mediating effect between halal awareness to halal purchase intention through halal technology implementation (0.016). Other result proved that halal awareness has insignificant value on halal purchase intention of packaging product in Semarang (0.412), halal awareness has significant value on halal technology implementation (0.000) and halal technology implementation has significant value on halal purchase intention (0.011).
\end{abstract}

Keywords: Halal Awareness, Halal Technology Implementation, Halal Purchase Intention, Packaging Product.

\begin{abstract}
Abstrak
Penelitian ini bertujuan untuk menganalisis niat pembelian halal yang dimediasi oleh penerapan teknologi halal pada produk kemasan di Kota Semarang, Indonesia. Penelitian ini
\end{abstract}


menganalisis konsep perilaku konsumen berbasis islamic branding technology. Model penelitian dikembangkan melalui variabel penelitian untuk mengisi kesenjangan penelitian yang ada antara kesadaran halal dan niat pembelian halal dengan implementasi teknologi halal. Teknologi ini mampu mendeteksi label halal yang divalidasi oleh MUI yang diharapkan memediasi kedua variabel. Pendekatan penelitian menggunakan pendekatan kuantitatif. Data dikumpulkan dengan metode survei kuesioner untuk konsumen kemasan produk di Semarang. Penelitian ini menggunakan purposive sampling untuk memperoleh 100 konsumen sebagai data pengamatan. Analisis SEM (Structural Equation Modell) digunakan untuk menganalisis data melalui menjalankan Smart PLS 3.2.8 untuk aplikasi Profesional untuk pengujian hipotesis. Temuan menunjukkan bahwa Perilaku Konsumen berdasarkan Konsep islamic branding technology terbukti. Hal ini dibuktikan dengan efek mediasi yang signifikan antara kesadaran halal dengan niat pembelian halal melalui penerapan teknologi halal (0.016). Hasil lainnya membuktikan bahwa kesadaran halal memiliki nilai tidak signifikan pada niat pembelian halal pada produk kemasan di Semarang (0.412), kesadaran halal memiliki signifikasi pada implementasi teknologi halal (0.000) dan implementasi teknologihalal memiliki signifikasi pada niat pembelian halal (0.011).

Kata Kunci: Kesadaran Halah Implementasi Teknologi Halah, Niat Beli Produk Halal, Produk Kemasan

\section{Introduction}

Halal certification is a halal recognition by Majelis Ulama Indonesia (MUI) on a product that is important especially for Muslim consumers. Nowadays, halal is not only to meet a religious obligation, but also has been viewed as a standard decision for Muslims as well as for Non-Muslims all over the world (Rezai, Mohamed, \& Shamsudin, 2012). Halal is one of the Muslim compliance concept (Golnaz, Zainalabidin, Mad Nasir, \& Eddie Chiew, 2010). A lot of people today also committed to a healthier lifestyle for cleaner food. Products and food produced according to the actual halal process can be accepted by both consumer either muslim or non-muslim. It makes halal food is becoming a new benchmark for all consumers because halal food is free from harmful ingredients as it basic principle of halal food products.

The existence of a halal label on a product is very important to give a consumer guarantee that the product fulfill halal requirement. Every country has its own halal certifier. In Indonesia, we have Majelis Ulama Indonesia (MUI) who has the task to certify halal products. If the products already get halal logo on its product, the trust from consumers to buy and use it products will increase. Based on The Republic of Indonesia Law No. 33 of 2014 regarding the guarantee of halal products, the provisions of halal products are based on ingredients and processing.

Globalization era is marked by rapid science and technology development, requires companies to be more creative and innovative to run and win business competition (Sjahdeini, 2018). We already know that there is a halal label of product that will lead people to understand what they should consume and use, but today we also have a halal branding technology that make it easier for consumer to 
check the halal status from the product that they want to buy. A lot of people in society still do not know about this.

Halal concept-awarenss should be shortly determined by society knowledge and involvement. On the other hand, the purchase intention is consumer decision that is affected by the halal awareness and we predict that it has a relationship with the knowledge of halal branding technology.

We decided to do research in Semarang because Semarang has the characteristics of a heterogeneous society. We took respondents from Semarang City and Regency. Semarang Regency is a regency in Central Java with the highest percentage of non-muslim population. The percentage of non-muslim population in Semarang regency reached $9.25 \%$. While for the city of Semarang, the total population of non-muslim residents reached 251.518 people. The number of nonmuslim population in the city of Semarang is the highest among other cities in Central Java. In Semarang city, the muslim and non-muslim interact well and live together harmoniously, as well as the city is a muslim majority city. Although the main target of Halal products is all Muslims in everywhere, it is important to see the purchase intention of the city that have a plurality of religion. From that opinion, the research model about the effect of Islamic Branding Awareness on Purchase Intention is worth studying in Semarang.

Pre-observation has been conducted to 40 consumers in Semarang, they have less intention to pay attention on Islamic brand when they will buy a certain packaging product. We conducted a pre-observation by distributing questionnaires to 40 respondents. The questionnaire contains some questions about their willingness to buy food and beverage products that have been circulating in the community. As many as $31.6 \%$ of respondents chose to buy snack products (snacks) that do not have a halal status on their products. As many as $61.4 \%$ of respondents thought a group of beverage brands did not have a halal label, when in fact it actually already had a halal label. This is because the brand is not as wellknown as other brands. People actually think other brands that are quite well known, already have the MUI halal label even though the reality does not yet have. Only $15.8 \%$ of respondents always identified the existence of the MUI halal label on packaging products they would buy.

Continuing the gap phenomenon that has been described previously, based on the results of previous research about Halal Awareness towards purchase intention has the controversy results. Consumer intent to purchase a product when they aware about Islamic branding that put-on product label (Ma'arifat, 2015). Otherwise brand awareness has insignificant value on purchase intention (Al Koliby \& Rahman, 2018). The above research gap requires a solution in reviewing brand awareness specially in Islamic branding awareness and dilemmatic in purchase intention in area that have many non-muslim society. The point is 
consumer behavior that pay attention on halal brand is need to analyze further to ensure halalness of product. Therefore, the concept that will be built in this research model is consumer behavior that used Islamic-branding technology based. Regarding the gap, certain factor indicates as solution to fill it. It is important to explore the role of technology that always makes people life easier so this research used halal technology implementation as mediating variable.

Based on the gap phenomenon that shows the number of non-muslim society in Semarang and lack of purchase intention of halal's product, and also based on research gaps in previous studies that show inconsistencies results between brand awareness and purchase intention, the problems in this research is: how to increase halal purchase intention of packaging product in Semarang?

\section{Literature review}

\section{Unity of Sciences}

Unity of Science (Wahdat al-'ulum) scientific unity, is a solution to avoid a dichotomy between religious science and science that is the cause of the decline of Muslims or it can also be interpreted that Unity of Science is a paradigm that asserts that all science is mutually dialogue and lead to one goal that is to deliver the observer to know and get closer to Allah, the True One (al-haqq). Unity of Science such as the integration of religious knowledge and science needs to be applied in many multidiscipline research.

The principles of unity of sciences include 1) Science must make its developers closer to God, 2) Make revelation as the first entrance, 3) Religious sciences must accept related non-religious sciences, 4) Modern sciences must accept the principle (monotheism), 5) Must recognize local wisdom that must be encouraged so that it colors this life (Yuliana, 2000). Halal concept in marketing studies could analyze well based on religious knowledge and sciences to get more comprehensive result.

\section{Consumer Behavior \& Decision Making Process}

There are many kind of consumer behavior, one of them is when they are buying something. When a business is faced with dynamic environmental changes, diversity in consumer demand and opportunities for business expansion that have good prospects, the tendency for businesses to diversify is higher (Savitri \& Alfizi, 2019). In that case consumen could make a selection process. Goods or service that have been needed by consumen and choosen from selecting, purchasing and 
consuming refferal named consumer buying behavior. The purpose of the consumen buying behavior is to fullfiled human nesassary and satisfy their wants.

Decision making is a applied theory from consumer behavior. In making a purchase decision consists of two types (Simon, 1979). Purchase decision making types is based on risk, certainty and uncertainty. The first type is the decision that are programmed (prommed decision), it is a decision that is made according to custom, rules or procedures. This decision type continues and repeats. Second, type of decision that are not programmed (non-prommed-decision) is decision relating to special or unusual problems. The function in decision making is crucial, decision making is the beginning of all conscious and directed human activities both individually and groups, both institutionally and organically. Decision making is futuristic, it means that it related to the future where has long effect.

A decision making can be effective if the decision brings an increase on the result. Consumer behavior related to purchase decision making, it begins with identifying and diagnosing problem, then collecting and analyzing data. The next process is the treatment of available alternatives (development, evaluation and selection) and it ends with the decision implementation. This decision making process decision-making process will determine people's purchasing behavior, shopping habit, the brand they choose or the retailer they go. Purchase decision is the result of consumer behavior factors (Ramya \& Ali, 2016). Ajzen said that behavior as a result of decision making process is early affected by intention (Ajzen, 1991).

\section{Technology Acceptance Model (TAM)}

Technological Acceptance Model (TAM) introduced by Fred D. Davis in 1989, was used to predict user acceptance of new technology using (Negara \& Savitri, 2019). The TAM model is the TRA (Theory of Reasoned Action) adoption model developed by Martin Fishbein and Icek Ajzen in the Information System field which is an action theory based on an assumption that a person's reaction and perception of something will determine the person's attitude and behavior. The main purpose of TAM is to provide a basis for tracing the influence of external factors on user beliefs, attitudes and goals. Further more, TRA states that individual behavior can be predicted from behavioral interest. The interest in behaving individually is influenced by two factors, such as attitude toward behavior and subjective norms. 
Technology acceptance suggests that acceptance of technology can be estimated by usefulness and ease of use. Technology facilitate condition that lead to individual trust the environment or informational as a good resource to enhance a better life quality (Rahman, Hanafiah, Abdul, \& Ruslee, 2016). There are many variables used in TAM. One of them is subjective norms / social influences. It means perception of the people who are important to them mostly think wheater he should or should not perform the behavior. Two factors that will estimate technology acceptance (by ease of use and usefulness) is determined perception leading to intentions to adopt new system (Lee, Kozar, \& Larsen, 2003).

Technology benefit and ease of use have an influence on behavioral interest. Technology users will have an interest using certain technology (behavioral interest) if they find the technology system which is useful and easy to use. Information system users will increasingly use the system if the information system is easy to use. otherwise, if the information system is not easy to use, then only fewer users use it (Negara \& Savitri, 2019).

Information technology is developing very rapidly over time. Characteristics of today's society, close to technology, including the internet (Chen \& Chao, 2011). Many applications are developed to facilitate human life. Various applications are developed by companies to improve the quality of service to the public. People can download the application for free and use it in their respective devices. Not only applies to companies, but government agencies also participate in developing service applications to the public. MUI as a halal certification council in Indonesia, helped create a breakthrough in halal branding technology in the form of Halal MUI application that can be used by the public to check whether or not a halal status is a product. In the Halal MUI application, we can scan barcodes, search for halal products by brand, halal certification, ask about the halal status of a product or process, find halal restaurants, and others.

\section{Halalness Concept}

The word Halal literally means lawful. In technical terms, it means the name given to the islamic legal things that are permissible. Halal is that which has been made lawful through our Beloved Prophet's Sunnah, Muhammad SAW and through the Holy Qur'an and hadist. The things which Allah has created and the benefits derived from them are essentially for man's use, and hence are permissible. Nothing is Haram except what is prohibited by explicit Nass from the Law-Giver. 
There are different degrees of Haram based on sharia perspective. It may be disliked, major amd minor. The right to make lawful and to prohibit is the Right of Allah. Concept of halal has been regulated in Qur'anic surah Al-Baqarah:2 (168169).

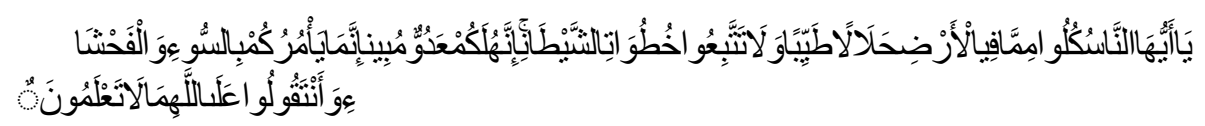

"O people! Eat of the lawful and pure things in the earth and follow not in the footsteps of Satan. For surely, he is your open enemy. he only commands you to do evil and commit acts of indecency and to ascribe to Allah the things concerning which you have no knowledge (that He really is their source)"

Allah SWT explains that there is no righteous worship except Allah and that Allah created itself. Allah also explained that Allah is capable of providing sustenance for all Allah's creatures. In terms of giving favors, Allah has allowed humans to eat everything on the earth, which is halal's food, good, and beneficial to themselves and does not harmful for human body and mind. Allah also forbade them to follow the steps and paths of Satan, in his actions which mislead Satan's followers, such as forbidding the good thing which were planted by Satan to them. The above message asks to absolutely eat halal food and forbid haram food.

Then, there are many concepts about halaness: halal, doubtful and haram. Muslims have to have enough awareness to differ them. Based on hadith below, muslims should avoid the doubtful (Bukhari no. 2051 and Muslim no. 1599).

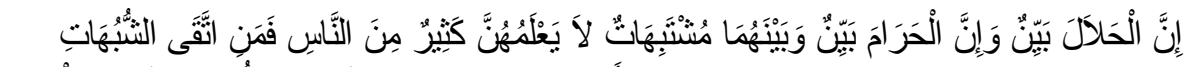

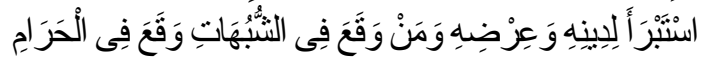

"The Halal (lawful) is clear and the Haram (prohibited) is clear, and in between them there are some things that are doubtful, which most people do not know - if they are Halal or Haram - Thus, whoever avoids the doubtful, safeguards his religion and honor, but one who engages in the doubtful, falls in the Haram."

The Hadith urges the believer's conscience to avoid doubtful actions since committing them could lure one to dare the prohibited actions themselves. This Hadith addresses Muslims which is the overseer whose duty is to see and take charge of work properly. Shortly, avoiding from committing doubtful actions and 
keeping away from Haram, belong Muslim's adherence to the halal criteria. This great Hadith leads us mentioning many rules concerning the Muslim's both individually behavior and in society.

More over, the hadith explain that Halal and Haram is very clear in Islam, although it belongs good intentions but it does not make the Haram acceptable and it absolutely prohibited to everyone. All the exeptions is dictated by necessity. The prohibition of things is due to their impurity and harmfulness (M. K. Abdullah, 2017).

This Hadith clearly states that keeping away from what is Haram and avoiding doubtful things and doing what is Halal. Our Beloved Prophet Muhammad SAW said: "human has achieved a complete faith is he/she who gives for Allah's sake, loves for His sake, prevents for Allah's sake, hates for His sake. Finally, our Iman will be perfect if we direct our activities and tendencies toward good and only for Allah's sake.

\section{Halal Purchase Intention}

Purchase Intention is the consumer tendency to take action related to the purchase and measured how far the buying-decision likelihood/possibility (Tjiptono, 2008). A statement which related to the mental condition which reflects the consumer plan to buy a brand at the certain time is intention to buy. Theory of Planned Behavior (TPB) which deals with antecedents of perceived behavioral control, attitude and subjective norms can explain purchase intention (Ajzen, 1991). These factors are used to understand people's intention to involve willingness to give activity directly or indirectly (Hrubes, Ajzen, \& Daigle, 2001). Based on the Planned Behavior Theory that is used as a basis for measuring consumer purchase intention, some researchers agree that intention is an indication to show individual beliefs to buy halal food products. So, halal purchase intention means consumer tendency to buy halal product (Budiman, 2019). This research uses many measurement indicators to predict halal purchase intention. They are: consumer have wanting to buy or not, consumer will buy or not and consumer will do repeat buying or not for food and drink packaging product (Nurcahyo \& Hudrasyah, 2017). 


\section{Halal Awareness}

Awareness is the ability to feel, perceive, and also to be conscious of objects and events. It is about implying knowledge understanding concept and perception toward the subjects or events. It is necessary for muslim consumer to have the halal awareness to consume halal products (Aziz \& Chok, 2013). Muslims who have halal component awareness tend to respect what they consume is trully halal. Muslims's strong belief on halal foods brings blessings and goodness in their life. Muslims should also take efforts to understand the concept of halalness. This research uses many measurement indicators to predict halal purchase intention. They are: the frequency of checking halal MUI existence in product label, able to differ the newest, old and fake Halal logo MUI, checking certificate number Halal MUI, halalness knowledge by MUI validation and belief in halalness logo without any website checking (Kristi, Benowo, Ramadan, \& Dewi, 2018).

\section{Halal Technology Implementation}

Technology is a tool that is used to provide goods for human need and bring human being comfort. In this modern era, when Muslims consume product, some of them are worries to the product that displays the halal label without ensuree about validity from a trusted certified institution (MUI). Competitors in the market today are increasing so this gives rise to a bad idea for producers to market their products. Products that do not have clear specifications will claim their products as halal products. This is one of MUI weakness to control fake halal label. In order to overcoming this problem, MUI makes applications in Play store that accessible and unlimited via mobile named "Halal MUI" application. Not only that, this application support recent halal website official MUI www.halalmui.org. Muslim should follow and adopt this technology to avoid doubtful thing (Syubhat). So, if many Muslim aware implement technology, it is helpful to obligate religious Sharia Law in consuming halal food. This research uses many measurement indicators to predict halal purchase intention. They are: labeling technology knowledge, checking process knowledge both website and application, experienced checking through website and application, 
checking success, belief is increasing by checking website and has already installed Halal MUI Application (Kristi et al., 2018).

The Effect of Halal Awareness on Halal Purchase Intention

Awareness is the ability to feel, perceive, and also to be conscious of objects and events. Awareness has been predicted as an important role in measuring the intention to select. Indonesian consumers already pay attention to halal label. This is evidenced by the increase in sales after the existence of halal label. The concept above indicates that people who have an intrinsic halal awareness will implements religious values in all aspects of his life according to belief religion that he embraces. They will really make sure the halal of what is consumed. Consumer intent to purchase a product when they aware about Islamic branding that put-on product label (Ma'arifat, 2015).

Awareness is an important role in determining intention to choose. Ahmad, Rahman, and Ab Rahman (2015) research showed that there is a significant influence between awareness and purchase behavior. Furthermore, if halal awareness level to halal food is high, the influence of awareness of purchasing decisions also positive and significant (R. Abdullah \& Razak, 2019). Previous studies proved that halal awareness, halal certification, marketing promotion, and brand were positively related to purchase intention (Aziz \& Chok, 2013). Similarly, Halal brand-awareness, satisfaction, trust and loyalty have positive significant effect to halal brand consumer purchase intention (Hrubes et al, 2001). Halal awareness will affect purchase intention improvement, otherwise lack of halal awareness will allow to decrease purchase intention. Based on above explanation, the following hypothesis are formulated for this study is:

H1: Halal Awareness have a significant value on purchase intention. The Effect of Halal Awareness on Halal Technology Implementation

Halal awareness is the halal concept and process knowledge that Muslims who considered use and consume product related to the moslem obidience important life. Halal definition is anything that is allowed or acceptable as muslim. One of the key determinants lead to consumer's adoption behavior is awareness, which is decided through particular product acquaintance. The crucial function of awareness is utilize innovative product as the best-known acts (Velmurugan \& Velmurugan, 2014). Muslims who have extrinsic factor will try to obtain 
information about product halalness in order to ensure they do not make mistake by doing forbidden thing. One of the way obtaining information is use application Halal MUI and checking website www.halalmui.org.

Halal awareness will affect halal technology implementation improvement, otherwise lack of halal awareness will allow to decrease halal technology implementation. The research of Kristi, Benowo, Ramadan and Dewi, proved positive significant relationship between consumer halal awareness and instant label MUI detector technology implementation (Kristi et al., 2018). It means that Muslim aware so much with halal food they will install application and visit website regularly to check product halalness through both technology that MUI had provided. Based on above explanation, the following hypothesis are formulated for this study is:

$\mathrm{H} 2$ : Halal Awareness have a significant value on halal branding technology.

The Effect Halal Technology Implementation on Halal Purchase Intention

Technology is the overall facility to provide goods needed to compete and comfort human life. Implementing the existence of technological developments that can be made to see product validity, including halal or non-halal products. Determining the halal and holiness of a food requires a comprehensive study that meet many multidisciplinary studies, such as pharmacy, food, bio-chemical material, industrial engineering and all about sharia knowledge understanding. Food before being traded can be tested first to get the halal label from the MUI. MUI Play an important role in ensuring that consumers get food that is free of illicit elements.

Purchase intention is strongly influenced by Muslim behavior that implement halal detector technology. To know the purchase intention, we need to first understand the level of consumer awareness of halal brand awareness through halal branding technology that is currently provided by MUI in the form of Halal MUI application. This has led to the implementation of technology for halal brands that will significantly influence the intention to buy halal products (Kristi et al., 2018). The intention of customers to buy certain brands can be formed through attitudes to recognize the characteristics of several additional brands (Shah et al., 2012). Studying brand characteristics must be considered as an important factor that has a big role in encouraging the habit of continuing to choose halal products for consumption (Vahdati \& Mousavi Nejad, 2016). The best way to encourage 
customers to buy is to create a strong brand and clear specifications such as the label or label of a halal product (Moisescu \& Bertoncelj, 2010).

When consumers already know the expected product specifications such as the halal label and the consumer has also checked the product using existing technology on each individual's mobile via the halal MUI application, the consumer will intend to buy the product. Consumers will volunteer to promote products to people around them if the product is safe and clear specifications for consumption. A recent study conducted by Ibrahim, Kassim and Mohamood concluded that existing technology on mobile phones can support the influence between awareness of the intention to purchase halal products (Ibrahim, Subari, Kassim, \& Mohamood, 2013). Based on above explanation, the following hypothesis are formulated for this study is:

H3: Halal Technology have a significant value on Purchase Intention.

\section{Research Methods}

The objects to be discussed in this study are consumer behavior in Semarang. This research will persuade customers who regularly consume packaging product with Islamic branding. Population is the whole of elements collection that have a number of general characteristics, which consist of fields to be examined. The sample is a portion of the amount that is owned by the population (Naresh, 1996). The sampling technique used by researchers was quota sampling. To get a sample by those technique to describe a population, then this research sample is respondent who fulfill certain criteria such as have minimum age 17 years old, muslim, ever have consume halal product. The number population about 100 respondents of muslim in Semarang will be choose to requires minimum number of sample requirement based Slovin formulation as follow with error standard (10\%) is 99.54 (100 respondent)

Primary data is used in this researh and also support by secondary data. Primary data is the data that was recorded and collected by researchers. While secondary data is data that is available in various forms (Arikunto, 2010). Secondary data sources are obtained from Badan Pusat Statistik (BPS) data, third parties who provide data needed like number of population number of muslim consumer in Semarang. Primary data in this study was obtained through distributing questionnaires to respondents, so that researchers obtained data from 
questionnaires filling conducted by respondents who consume packaging product. In distributing questionnaires researchers realized that not all questions were understood by respondents. Therefore, the researcher helped explain the questions in the questionnaire. Data analyzing used Structural Equation Model (SEM) method. The SEM process cannot be done manually, so researchers use a tool in the form of software Smart PLS 3.2.8 for Professionals for hypothesis testing.

\section{Result and Discussion}

Respondents Profile

Table 1. Respondents Profile

\begin{tabular}{|c|c|c|c|c|}
\hline No & Variable & Category & Frequency & $\%$ \\
\hline \multirow[t]{2}{*}{1} & \multirow[t]{2}{*}{ Gender } & Male & 46 & 46.0 \\
\hline & & Female & 54 & 54.0 \\
\hline \multirow[t]{4}{*}{2} & \multirow[t]{4}{*}{ Age } & $17-25$ & 72 & 72.0 \\
\hline & & $26-30$ & 24 & 24.0 \\
\hline & & $36-40$ & 2 & 2.0 \\
\hline & & $>40$ & 2 & 2.0 \\
\hline \multirow[t]{4}{*}{3} & \multirow{4}{*}{ Education } & College & 62 & 62.0 \\
\hline & & Diploma & 2 & 2.0 \\
\hline & & Bachelor & 28 & 28.0 \\
\hline & & Master \& Doctor & 8 & 8.0 \\
\hline \multirow[t]{5}{*}{4} & \multirow[t]{5}{*}{ Revenue } & $<$ IDR 2.5jt & 77 & 77.0 \\
\hline & & IDR $2.5-5 j \mathrm{t}$ & 12 & 12.0 \\
\hline & & IDR 5 - 10jt & 5 & 5.0 \\
\hline & & IDR $10-15 \mathrm{jt}$ & 4 & 4.0 \\
\hline & & IDR $>15 \mathrm{jt}$ & 2 & 2.0 \\
\hline
\end{tabular}

The table above shows that participants who participated in the study consist female participant number is 54 (54\%) and the number of male is $46(46 \%)$. They mostly have collage level education around $62(62 \%)$, participants were born around 1994 2003 are $72(72 \%)$. It means, they are mostly millennial generation. Millennial generation usually has higher awareness on technology than baby boomer's generation. Seventy-seven participant's revenues are less than IDR 2.500 .000 (77\%). It shows that 
participant still attended as a university student or as a newbie worker.

\section{Validity test}

Based on the convergent validity test, there are several variables that do not required validity criteria, so the invalid indicators are eliminated. After eliminating invalid indicator and repeat running for algorithm equation, the results of the validity test indicate that the indicator has required convergent validity with loading factor value more than 0.5 (Ghozali, 2014).

\section{Table 2. Validity test}

\begin{tabular}{lllllr}
\hline \multirow{2}{*}{ Indicator } & \multicolumn{2}{c}{ Loading Factor } & Indicator & \multicolumn{2}{c}{ Loading Factor } \\
\cline { 2 - 5 } \cline { 3 - 6 } & $\begin{array}{c}\text { Before } \\
\text { Drop }\end{array}$ & $\begin{array}{c}\text { After } \\
\text { Drop }\end{array}$ & & $\begin{array}{c}\text { Before } \\
\text { Drop }\end{array}$ & After drop \\
\hline HA1 & 0.518 & 0.525 & \multicolumn{1}{l}{ HP1 } & 0.800 & 0.797 \\
HA2 & 0.898 & 0.895 & HTI1 & 0.546 & 0.571 \\
HA3 & 0.769 & 0.778 & HTI2 & 0.713 & 0.719 \\
HA4 & 0.904 & 0.901 & HTI3 & 0.716 & 0.747 \\
HA5 & 0.211 & - & HTI4 & 0.738 & 0.728 \\
HPI1 & 0.932 & 0.935 & HTI5 & 0.877 & 0.882 \\
HP12 & 0.922 & 0.925 & HTI6 & 0.803 & 0.804 \\
HP13 & 0.833 & 0.830 & HTI7 & 0.463 & - \\
HP14 & 0.854 & 0.851 & HTI8 & 0.717 & 0.727 \\
HP15 & 0.819 & 0.815 & & & \\
& & & & & \\
\hline
\end{tabular}

Notes: Halal Awareness (HA); Halal Technology Implementation (HTI); Halal Purchase Intention (HPI)

\section{Reliability Test}

The reliability test result is obtained pc values of all variable are more than 0.6 in range 0.864 to 0.945 . it means that the item questions that compose a variable have high internal consistency and can be continued to next phase for full model analysis testing. 
Table 3. Reliability Test

\begin{tabular}{lc}
\hline & Composite Reliability \\
\hline Halal Awareness & 0.864 \\
\hline Halal Purchase Intention & 0.945 \\
\hline Halal Technology Implementation & 0.896 \\
\hline
\end{tabular}

Determination Coefficient Test

Table 4. Determination Coefficient Test

\begin{tabular}{lll}
\hline & Adjusted R Squared \\
\hline Halal Purchase Intention & 0.154 \\
Halal Technology Implementation & 0.430 \\
\hline
\end{tabular}

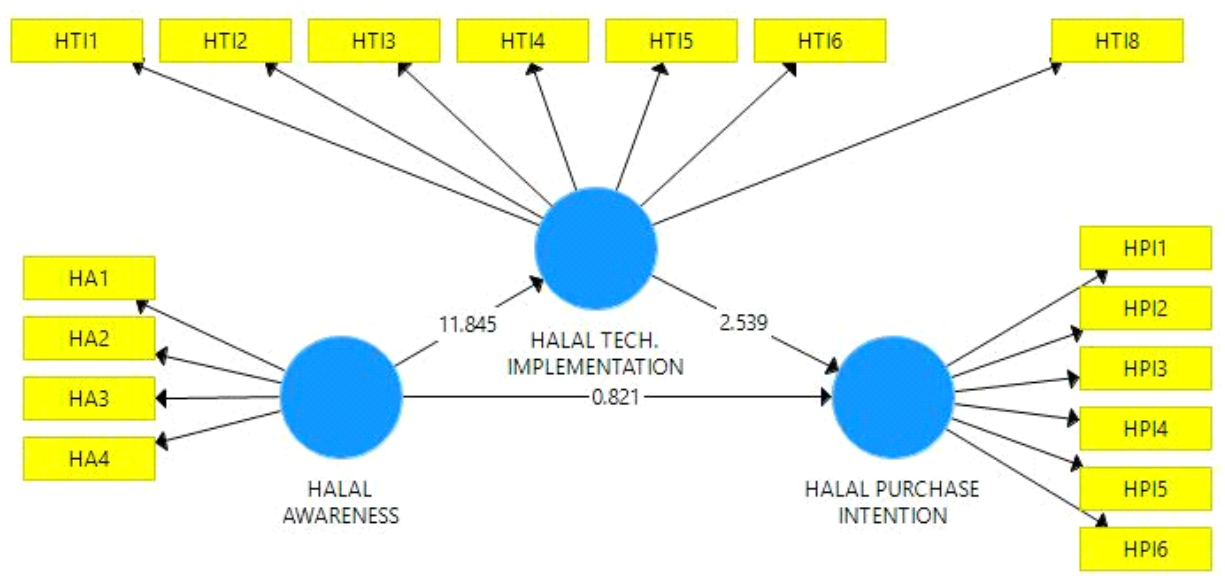

Figure 1. PLS Bootstrap

Based on determination test, the independent variable ability when explaining the dependent variable variation is shown by adjusted R-squared value. Halal technology implementation variable has coefficient value amount $0.430(43.0 \%)$ and halal purchase intention has coefficient value amount 0.154 (15.4\%). This coefficient value can be interpreted that the independent variables explain halal purchase intention variable is quite low only amount $0.154(15.4 \%)$ and 0.846 $(84.6 \%)$ is explained by other measuring variable outside research model. After 
testing the instrument (validity \& reliability) and measuring fit model (determination), the next step is to test the hypothesis as follows.

\section{PLS Bootstrap}

Based on the PLS Bootstrap equation, it is known that the relationship between halal awareness and halal purchase intention is insignificant, it has been seen from the $t$-statistic value of 0.412 which is less than $t$-table \pm 1.96 . Based on these result, it can be concluded that first hypothesis (H1) is rejected. The interaction of halal awareness variable and halal technology implementation has a significant effect that is shown by $\mathrm{t}$-statistic value of 11.845 which is more than $\mathrm{t}$ table \pm 1.96 . Thus the analysis result of second hypothesis $(\mathrm{H} 2)$ is proved. Furthermore, halal technology implementation is proved affect halal purchase intention with significant $t$-statistical value of 2.539 which is more than $t$-table \pm 1.96 . The analysis result has accepted third hypothesis (H3).

Based on PLS Bootstrap analysis (Specific Indirect Effects), halal technology implementation has been proved mediating halal awareness toward halal purchase intention. It can be seen from $\mathrm{t}$-statistic value of 2.416 which is more than $\mathrm{t}$-table \pm 1.96 . The higher halal awareness will increase halal technology implementation that will affect halal purchase intention improvement.

\section{Table 5. The higher halal awareness will increase halal technology implementation}

\begin{tabular}{|c|c|c|c|c|c|}
\hline Bootstrap Path Coefficient & $\begin{array}{l}\text { Original } \\
\text { Sample }\end{array}$ & $\begin{array}{l}\text { Sample } \\
\text { Mean }\end{array}$ & $\begin{array}{l}\text { Standard } \\
\text { Deviation }\end{array}$ & $\begin{array}{l}\mathrm{T} \\
\text { Statistics }\end{array}$ & $\begin{array}{l}\mathrm{P} \\
\text { Values }\end{array}$ \\
\hline \multicolumn{6}{|l|}{ Path Coefficient Direct Effect } \\
\hline \multicolumn{6}{|l|}{ Halal Awareness -> Halal } \\
\hline Purchase Intention & 0.118 & 0.125 & 0.144 & 0.821 & 0.412 \\
\hline \multicolumn{6}{|l|}{ Halal Awareness -> Halal } \\
\hline Technology Implementation & 0.660 & 0.670 & 0.056 & 11.845 & 0.000 \\
\hline \multicolumn{6}{|l|}{ Halal Technology } \\
\hline \multicolumn{6}{|l|}{ Implementation $->$ Halal } \\
\hline Purchase Intention & 0.325 & 0.329 & 0.128 & 2.539 & 0.011 \\
\hline \multicolumn{6}{|l|}{ Specific Indirect Effect } \\
\hline \multicolumn{6}{|l|}{ Halal Awareness -> Halal } \\
\hline \multicolumn{6}{|l|}{ Technology Implementation } \\
\hline ->Halal Purchase Intention & 0.215 & 0.220 & 0.0089 & 2.416 & 0.016 \\
\hline
\end{tabular}




\section{The Effect of Halal Awareness on Halal Purchase Intention}

Awareness is a thinking mindset that implies the ability to feel, understand, and become aware of things, events. Awareness plays an important role determining intention to choose (Aziz \& Chok, 2013). Halal principles is based on positive attitudes, It will determine consuming or buying behavior especially for halal products. Refer to background factors that determine intention, personality could able to make individual having enough responsiveness to take future behavior (Ajzen, 2005). The impact of awareness on halal purchase intention is caused by a Muslim's religion life that has become a habit. So, all life aspect will be based on religious beliefs. The religious beliefs will lead people to obey the religion rules.

Indonesian has already paid attention on halal label but Muslim's has various perception and belief. some of them prioritized checking halal label first before buying, others did not do that. They always buy packaging product in a trustable places or event buy some popular packaging product so no need to check halal label in their product. Muslim's various perception and belief determined their behavior and attitude in decision making to purchase halal product.

There are two kinds of religion factor that make people shows different behavior, namely intrinsic and extrinsic. Intrinsic factor combining religious values inside, then spiritual internalization in intrinsic factor has low prejudice. Otherwise extrinsic factor means that there is a high level of religious prejudice, the way extrinsic religion encourages a person to utilize his/her religion. The concept shows that people who have intrinsic traits of halal awareness will apply religious values in all aspects of life according to their religious beliefs, whereas extrinsic traits of halal awareness will follow the religion commitment through information obtained, such as seeing halal information from products label.

The research finding is supported by previous research conducted by $\mathrm{Al}$ Koliby and Rahman (2018) that conduct his research on Malaysia. Awareness belongs brand equity dimension that cannot affect purchase intention. Nurcahyo \& Hudrasyah also proved that there is insignificant effect between awareness of halal product and people's intention to choose halal products (Nurcahyo \& Hudrasyah, 2017). Therefore, halal awareness is conceptualized as an obtaining information process to increase awareness level about what Muslims are allowed to eat, drink and use (Ambali \& Bakar, 2013). Obtaining information process in halal packaging product is not fully determine decision to consume. 


\section{The Effect of Halal Awareness on Halal Technology Implementation}

A symbol of cleanliness reflects products halalness, high quality and safety for Muslim consumer (Kristi et al., 2018). Halal certification is a security guarantee for Muslims to buy a product that can be identified by halal logo existence on the product label (Aziz \& Chok, 2013). In general, halal approaches in product marketing process can neutralize negative image. It will be associated with a Muslim when consuming product. In modern era, halal products are widely available and many research about halal product market (Alam \& Sayuti, 2011). Various research provides many theory, concept and its development in purchase halal food behavior.

In some cases, there are knowledge deficiencies between concepts determining halal product and attitude to consume that called halal awareness (Aziz \& Chok, 2013). Awareness of halal product is balanced with good knowledge for product assessment that should not contain illicit ingredients or should be forbidden to consume by Muslim based on religion rule. As a good muslim, it is better to identified halal logo first before purchase a product.

Mostly people of Indonesia are muslim, their life guidance based on Islamic Sharia. Nowadays, when people purchase a product, it is not enough to identified halal logo on product label. There are many product suppliers that has no commitment to serve halal product regularly or even they put a fake halal logo. It is hard to identified which product has a valid halal logo or has invalid one because consumers have limitation that related to knowledge deficiencies and less effort to obtain information. Therefore, a technology is developed to facilitate the instant label of the original MUI. So, by implementing halal technology that can detect validity of MUI's halal logo can ensure valid information for Muslim consumers. This finding is consistent with previous research conducted by Kristi, Benoowo. Ramadan and Dewi, it proved positive significant relationship between consumer halal awareness and instant label MUI detector technology implementation (Kristi et al., 2018).

\section{The Effect of Halal Technology Implementation on Halal Purchase Intention}

Technology is a whole tool to provide goods needed for human life sustainability and comfort. The food products processing need to be facilitated 
Muslim in selecting halal food. LPPOM-MUI that stands for Foods, Drugs, and Cosmetics Assessment Institute - Indonesian Council of Ulama has provided webbased information to help consumers to trace the validity of halal status on the product package (Giyanti, Suparti, \& Sutopo, 2019). That is one of the facilitation example to trace halal validity. Nowadays, MUI provide application to reduce the difficulties in web tracing.

MUI Plays an important role in ensuring that consumers get food that without forbidden elements. Food or product that are clearly halal based on Islamic law will significantly influence consumer's halal purchase intentions. LPPOM-MUI has responsibilities to control medicine, cosmetic, food, drink or many packaging products by giving halal status. In fact, people will not intend to buy a product that does not have MUI halal logo. That is the easy way to identify. Continuing above phenomena leads to fake halal logo. Further action by tracing validity is needed. Website halalmui.org and Halal MUI apps is considered to be the easiest to see whether the product is worth it to buy or not. This has led to the implementation of technology for halal brands. It will significantly influence the intention to buy halal products in accordance with what is done (Kristi et al., 2018).

Based on the finding, it can be explained that LPPOM-MUI needs provide facilitation to ensure Muslims consumers when purchase a product. The higher technology implementation that is provided by LPPOM-MUI and it is also wisely used by the user (muslim consumers) will increase halal purchase intention because Muslims have beliefs in obtaining valid information by crosscheck it. Otherwise, when technology implementation has low applicability by both side, it will decrease halal purchase intention.

\section{The Effect of Halal Awareness on Halal Purchase Intention through Halal Technology Implementation}

Intention to buy certain brands can be formed through attitudes to recognize the characteristics of several additional supported brands (Shah et al., 2012). Characteristics learning of a brand must be considered as an important factor and has a big role to encourage the habit choosing halal products for consumption (Vahdati \& Mousavi Nejad, 2016). The customer's willingness to buy certain products is conceptualized in purchase intention as a marketing field focus. The best way to encourage customers to buy is to create a strong brand and clear 
specification such as halal logo in product label as an additional supporting brand (Moisescu \& Bertoncelj, 2010). The brand strength has been taken in consumers memory. The brand strength will reflect the ability to know or see through website or halal MUI application to ensure for consume in accordance with religious advice. The way customers obtaining halal information about a brand itself represents customer awareness of a halal packaging product. Previous research has focused discussing awareness context, the process of knowing user information first and expecting service provision through today's emerging technology.

There are some steps before customer decide to purchase. First, customer should aware with halal product, the awareness is showed by knowledge they have, by the effort obtaining product information and of course aware about technology availability to trace the halalness validity. Second step, after customer already has known the expected product specifications such as the halal label, consumer also check on the product using existing technology on each individual's mobile via the halal MUI application or website halalmui.org. Finally, the consumer will intend to buy the product because of strong intention. A recent study conducted by Ibrahim, Subari, Kassim and Mohamood concluded that existing technology can mediate the influence between awareness of the intention to purchase halal products (Ibrahim et al., 2013). The strength of the brand to be taken in the memory of consumers is reflected by the ability of customers to know or see through the website or halal MUI application to be safe for consumption in accordance with religious advice. Mediating role of technology implementation on this research is being a guarantee of validity halalness product.

\section{Conclusion}

From above overall discussion, it can be concluded that halal awareness has insignificant value on halal purchase intention of packaging product in Semarang; halal awareness has significant value on halal technology implementation; halal technology implementation has significant value on halal purchase intention and halal awareness has significant value on halal purchase intention through halal technology implementation.

This finding bring benefit for many parties. First, suppliers should have a strong commitment to consumer that will always provide halal product. Fake halal logo from irresponsibility's supplier can be minimize rapidly. Second, consumer able to 
find out the easiest way tracing halalness validity to ensure and recommend others. Finally, these findings contribute further consumer behavior analysis which provide new concept called Consumer Behavior based on Islamic Branding Technology.

This research has limitation in sample obtaining and only used three variables. We can see the determination coefficient on halal purchase intention is too weak. The participant respond is objective so only used a single method to analyze the data.

Future research recommends to modify the further research model if possible so that it can fill in the gaps by other solution variables. In addition, the model can also be analyzed in each age segment, occupation \& other demographic characteristic. Further research is expected to analyze more deeply through indepth interviews in order to obtain subjective significant results. So, detail information how to increase halal purchase intention successfully explain well. Mixed method design also can be used as an integrated analysis method to examine deeply by using indicators formulated through pre-survey triangulation, so that service companies determine the right management strategy. This study should increase the number of samples through the cluster sampling method in order to obtain more observational data. It also can analyze the response and perception in each consumer segment obtain specific and representative results.

\section{REFERENCES}

Abdullah, M. K. (2017, 28 September 2017). The Doubtful Things Between Halal and Haram,. Retrieved Mei, 2018

Abdullah, R., \& Razak, L. A. (2019). The effect of halal foods awareness on purchase decision with religiosity as a moderating variable. Journal of Islamic Marketing.

Ahmad, A. N., Rahman, A. A., \& Ab Rahman, S. (2015). Assessing knowledge and religiosity on consumer behavior towards halal food and cosmetic products. International Journal of Social Science and Humanity, 5(1), 10.

Ajzen, I. (1991). The theory of planned behavior. Organizational behavior and human decision processes, 50(2), 179-211.

Ajzen, I. (2005). Attitudes, personality, and behavior. New York: McGraw-Hill Education (UK). 
Al Koliby, I. S., \& Rahman, M. A. (2018). Influence Dimensions of Brand Equity on Purchase Intention Toward Smartphone in Malaysia. VFAST Transactions on Education and Social Sciences, 15(1), 7-19.

Alam, S. S., \& Sayuti, N. M. (2011). Applying the Theory of Planned Behavior (TPB) in halal food purchasing. International journal of Commerce and Management.

Ambali, A. R., \& Bakar, A. N. (2013). Halāl food and products in Malaysia: People's awareness and policy implications. Intellectual Discourse, 21(1).

Arikunto, S. (2010). Prosedur Penelitian Suatu Pendekatan Praktik. Jakarta: Rineka Cipta.

Aziz, Y. A., \& Chok, N. V. (2013). The role of Halal awareness, Halal certification, and marketing components in determining Halal purchase intention among non-Muslims in Malaysia: A structural equation modeling approach. Journal of International Food \& Agribusiness Marketing, 25(1), 1-23.

Budiman, R. (2019). Factors Influencing Purchase Intention of Halal Products in Pontianak City. Indonesian Journal of Halal Research, 1(2), 46-48.

Chen, C.-F., \& Chao, W.-H. (2011). Habitual or reasoned? Using the theory of planned behavior, technology acceptance model, and habit to examine switching intentions toward public transit. Transportation research part F: traffic psychology and behaviour, 14(2), 128-137.

Ghozali, I. (2014). SEM Metode Alternatif dengan menggunakan Partial Least Squares (PLS). Semarang: Badan Penerbit Universitas Diponegoro.

Giyanti, I., Suparti, E., \& Sutopo, W. (2019). Predicting Online Search Intention for Validating Product Halalness Status. Paper presented at the Proceedings of the International Conference on Industrial Engineering and Operations Management.

Golnaz, R., Zainalabidin, M., Mad Nasir, S., \& Eddie Chiew, F. (2010). NonMuslims' awareness of Halal principles and related food products in Malaysia. International food research journal, 17(3), 667-674.

Hrubes, D., Ajzen, I., \& Daigle, J. (2001). Predicting hunting intentions and behavior: An application of the theory of planned behavior. Leisure Sciences, 23(3), 165-178.

Ibrahim, I. I., Subari, K. A., Kassim, K. M., \& Mohamood, S. K. B. (2013). Antecedent stirring purchase intention of Smartphone among adolescents in Perlis. International Journal of Academic Research in Business and Social Sciences, 3(12), 84 . 
Kristi, J., Benowo, M. A. P., Ramadan, I. C. P., \& Dewi, R. S. (2018). Analisis Pengaruh Perilaku Konsumen Sadar Halal terhadap Penerapan Technology Pendeteksi Instan label MUI. Prosiding SNST Fakultas Teknik, 1(1).

Lee, Y., Kozar, K. A., \& Larsen, K. R. (2003). The technology acceptance model: Past, present, and future. Communications of the Association for information systems, 12(1), 50.

Ma'arifat, T. N. (2015). Analisis Perilaku Konsumen Dalam Pembelian Makanan Olahan Ayam Bersertifikat Halal Di Ritel Modern Yogyakarta. Prosiding Seminar Agroindustri dan Lokakarya Nasional FKPT-TPI Program Studi TIP-UTM, 2-3.

Moisescu, O. I., \& Bertoncelj, A. (2010). A Comparative Study of The Relationship Between Brand Loyalty and Market Share Among Durable and Non-Durable products. Management \& Marketing Journal, 8(1).

Naresh, M. (1996). Marketing Research and Applied Orientation. . USA: Prentice Hall International.

Negara, I. S. M., \& Savitri, F. M. (2019). Analisis Penerimaan Penggunaan Sistem Informasi Akademik, Studi Kasus STIKES Harapan Bangsa. Solusi, 17(3).

Nurcahyo, A., \& Hudrasyah, H. (2017). The influence of Halal awareness, Halal certification, and personal societal perception toward purchase intention: a study of instant noodle consumption of college student in Bandung. Journal of Business and Management, 6(1), 21-31.

Rahman, A. A., Hanafiah, M. H., Abdul, M., \& Ruslee, A. A. (2016). Assessing consumers' willingness to use tagging technology in tracing halal status. International Journal of Islamic Marketing and Branding, 1(3), 272-284.

Ramya, N., \& Ali, M. (2016). Factors affecting consumer buying behavior. International joumal of applied research, 2(10), 76-80.

Rezai, G., Mohamed, Z., \& Shamsudin, M. N. (2012). Non-Muslim consumers' understanding of Halal principles in Malaysia. Journal of Islamic Marketing.

Savitri, F. M., \& Alfizi, A. (2019). Mediasi Strategi dalam Hubungan Pembelajaran Organisasi terhadap Kinerja Bisnis. Solusi, 17(3).

Shah, S. S. H., Aziz, J., Jaffari, A. R., Waris, S., Ejaz, W., Fatima, M., \& Sherazi, S. K. (2012). The impact of brands on consumer purchase intentions. Asian Journal of Business Management, 4(2), 105-110.

Simon, H. A. (1979). Rational decision making in business organizations. The 
American economic review, 69(4), 493-513.

Sjahdeini, S. R. (2018). Larangan Praktik Monopoli dan Persaingan Usaha Tidak Sehat. Jurnal Hukum Bisnis, 6(4).

Tjiptono, F. (2008). Strategi Pemasaran, Edisi III, CV. Andi Offset, Yogyakarta.

Vahdati, H., \& Mousavi Nejad, S. H. (2016). Brand Personality Toward Customer Purchase intention: The Intermediate Role of Electronic Word-Of-Mouth and Brand equity. Asian Academy of Management Journal, 21(2).

Velmurugan, M. S., \& Velmurugan, M. S. (2014). Consumers' awareness, perceived ease of use toward information technology adoption in $3 \mathrm{G}$ mobile phones' usages in India. Asian Journal of Marketing, 8(1), 1-23.

Yuliana, E. D. (2000). Pentingnya pendidikan karakter bangsa guna merevitalisasi ketahanan bangsa. Buletin Udayana Mengabdi, 9(2). 